\title{
Assessment of environmental soil quality around Sonepur Bazari mine of Raniganj coalfield, India
}

\author{
R. E. Masto, S. Sheik, G. Nehru, V. A. Selvi, J. George, and L. C. Ram \\ Environmental Management Division, CSIR - Central Institute of Mining and Fuel Research (Digwadih Campus), \\ Dhanbad 828108, India \\ Correspondence to: R. E. Masto (mastocfri@yahoo.com)
}

Received: 31 December 2014 - Published in Solid Earth Discuss.: 10 February 2015

Revised: 09 June 2015 - Accepted: 14 June 2015 - Published: 08 July 2015

\begin{abstract}
Assessment of soil quality is one of the key parameters for evaluation of environmental contamination in the mining ecosystem. To investigate the effect of coal mining on soil quality, opencast and underground mining sites were selected in the Raniganj coalfield area, India. The physical, chemical, and biological parameters of the soils, and trace metals and PAHs (polycyclic aromatic hydrocarbons) in the soils were evaluated. Soil dehydrogenase $(+79 \%)$ and fluorescein $(+32 \%)$ activities were significantly higher in underground mine (UGM) soil, whereas peroxidase activity $(+57 \%)$ was higher in opencast mine (OCM) soil. Content of As, $\mathrm{Be}, \mathrm{Co}, \mathrm{Cr}, \mathrm{Cu}, \mathrm{Mn}, \mathrm{Ni}$, and $\mathrm{Pb}$ was significantly higher in OCM soil, whereas Cd was higher in UGM. In general, the PAHs contents were higher in UGM soils, probably due to the natural coal burning at these sites. The observed values for the above properties were converted into a unitless score (0-1.00) and the scores were integrated into an environmental soil quality index (ESQI). In the unscreened index (ESQI-1) all the soil parameters were included and the results showed that the quality of the soil was better for UGM (0.539) than the OCM (0.511) soils. Principal component analysis was employed to derive ESQI-2 and accordingly, total PAHs, loss on ignition, bulk density, Be, $\mathrm{Co}, \mathrm{Cr}, \mathrm{Ni}, \mathrm{Pb}$, and microbial quotient (respiration: microbial biomass ratio) were found to be the most critical properties. The ESQI-2 was also higher for soils near UGM $(+10.1 \%)$. The observed indicators and the ESQI results revealed that soil quality assessment for these coal mining soils is largely depended on soil PAHs and potentially toxic trace metals. The proposed ESQI may be further refined by incorporating specific parameters related to human exposure risks and exposure pathways.
\end{abstract}

\section{Introduction}

Coal, a combustible rock rich in carbon, is a crucial component of the energy mix that fuels the globe. In many countries, more than $70 \%$ of the electricity generation comes from coal. For more than 150 years, coal has been an important source of energy for both developing and industrial societies. Coal mining is one of the core industries and plays a positive role in the economic development of any country. Its environmental impact cannot be ignored but, to some extent, is unavoidable (Chaulya, 2004). Many of the environmental and health problems attributed to coal are due to mobilization of potentially toxic organic and inorganic components (Swaine and Goodarzi, 1995). Coal is extracted from the earth by opencast and underground mining. Opencast mining is considered one of the most dramatic disturbances in terrestrial ecosystems. The disturbances to green vegetation due to mining and the difficulty for restoration have been reported (Milder et al., 2013).

Coal mining can contaminate the nearby soils through atmospheric deposition, and is one of the most common sources of pollution in soil (Mondal et al., 2010). Ghose (2007) estimated that a typical open-pit coal mine in India emitted $9366.7 \mathrm{~kg} \mathrm{day}^{-1}$ of total suspended particles (TSP) which accounts for $3.74 \mathrm{~kg}$ of TSP per $\mathrm{Mg}$ of coal produced. Various mining operations like top-soil handling, drilling, blasting, overburden-handling by draglines and conveyors; coal handling, loading, unloading, etc. generate huge amounts of dust and ultimately settle on nearby soils (Masto et al., 2011b). Vegetation on the mine spoil may help to control the coal dust deposition, soil erosion, sedimentation, etc. (Keesstra et al., 2009; Keesstra, 2007; Das et al., 2014; Zhao 
et al., 2015), and eventually soil quality, depending on the plant species (Zhang et al., 2015).

Coal dust contains metal species like $\mathrm{Fe}, \mathrm{Cu}, \mathrm{Zn}, \mathrm{Mn}$, $\mathrm{Pb}, \mathrm{Cd}, \mathrm{Cr}, \mathrm{Ni}, \mathrm{Co}, \mathrm{V}, \mathrm{Ti}, \mathrm{Br}, \mathrm{Zr}$, etc. and organic pollutants. Metal pollution from coal is of concern because some of the elements have high enrichment factors (Masto et al., 2007b). Bi is considered as highly enriched in coal with a factor > 10, whereas $\mathrm{As}, \mathrm{Cd}, \mathrm{B}, \mathrm{Sb}, \mathrm{Mo}$, and $\mathrm{Hg}$ are less enriched (factor 2-10). Most of the heavy metals are essential elements for living organisms, but their excess amounts are generally harmful to plants, animals, and human health (Jarup, 2003). Coal also contributes to PAHs (polycyclic aromatic hydrocarbons) in the environment. PAHs are characterized by their exceptional toxicities towards many living organisms, reluctance in degradation, and high lipophilicity (Okedeyi, 2012), making them a class of very dangerous compounds. Coals exhibit relatively high PAH concentrations (Stout and Emsbo-Mattingly, 2008; Willsch and Radke, 1995), and soil admixed with coal particles has elevated PAH concentrations (Pies et al., 2007).

Mining affects surface vegetation and soil quality. Soil is an invaluable natural resource and its quality must be conserved and sustained. The environmental, social, economic, geologic, and human health issues are related to the quality of the soil (Brevik et al., 2015). Soil has all varieties of life-dwelling habitat, both below- and aboveground. Soil biodiversity supplies many ecosystem services essential to humans and the environment. Soil quality is linked with human health in many ways (Zornoza et al., 2015). Soils are under increasing environmental pressure, and this affects the capacity of the soil to continue to perform its functions. However, the extent, severity, and consequences of soil degradation are poorly documented and there is an urgent need for quantitative determination of soil quality (Brevik et al., 2015).

Soil is also a good indicator of pollution and environmental risks. It is continuously subjected to pollution because of its open-system nature. Soil, an important natural resource, supports plant growth and other human needs (Masto et al., 2011a). But, the presence of pollutants can affect soil quality and impair its life-sustaining capacity. It is therefore important to identify the soil characteristics responsible for changes in soil quality, which may eventually be considered as soil quality indicators for assessing environmental sustainability (Masto et al., 2007a). Integrated soil indices, based on a combination of soil properties, provide a better indication of soil health than individual properties. Moreover an integrated index is essential for quantitative comparison of different soils. Several indices have been proposed to assess soil quality, which were mostly microbial in nature and for agricultural soils (Sharma et al., 2005; Masto et al., 2007a, 2008a, b; Ozgoz et al., 2013; Sinha et al., 2009; MorugánCoronado et al., 2013; van Leeuwen et al., 2015). Indexing involves three main aspects: (1) choosing appropriate indicators for a minimum data set, (2) transforming the indicators to scores, and (3) combining the scores into an index (Sinha et al., 2009). Soil quality indices are useful to differentiate between the degraded status of soils (Morugán-Coronado et al., 2013). Though there are a few studies on the assessment of soil parameters on coal mine soil (Mukhopadhyay and Maiti, 2014; Tizado and Núñez-Pérez, 2014; Pallavicini et al., 2015; Haigh et al., 2015; Chaudhuri et al., 2015), integrated estimation of soil quality is limited.

A mine-soil quality index (SQI) has been used for a selection of tree species suitable for reclamation (Sinha et al., 2009; Mukhopadhyay et al., 2013). In a reclaimed coal mine spoil, SQI progressively increased with the age of reclamation. SQI varied from 0.220 in a 2 year-old reclaimed dump to 0.670 in a 17 year-old reclaimed dump. Mine soil with a SQI $>0.500$ may be considered as ecologically sustainable or reclamation is satisfactory (Mukhopadhyay et al., 2014). In metal-contaminated mine soil, the SQI was higher for the reclaimed site than the un-reclaimed areas (Asensio et al., 2013). In another reclaimed site, the quality of surface soil was higher than that of subsoil, especially after the application of mushroom-waste (Guo et al., 2013). Pietrzykowski (2014) reported some guidelines that can be employed to assess reclaimed-mine-soil quality.

In the last decade, global energy demand has increased tremendously, consequently coal mining and land degradation has been significantly enhanced. Unlike air and water quality, soil quality is not given emphasis in mining areas, as soil is not directly consumed by human beings. Moreover, the assessment of soil quality is complicated due to the heterogeneous nature of soil, and its quality assessment is largely depended on the intended use of the soil (Zornoza et al., 2015). Most of the past SQI studies on mine spoils were focussed on evaluating the success of reclamation. The status of soil quality during mining activities is very important, especially in identifying the potential adverse impact on nearby soil and to initiate interventions and modifications in ongoing mining projects. The physical, chemical, and biological properties and toxic constituents of soil determine its overall quality. Soil quality cannot be measured by a single soil parameter; integrated multiple soil criteria are to be considered for assessing soil quality. The present study aimed to assess the physical, chemical, and biological parameters of the soil, along with trace metal and PAH contents in the soil near an opencast and underground coal mine. The other objective was to integrate all these parameters into a comprehensive environmental soil quality index (ESQI).

\section{Materials and methods}

\subsection{Study site and soil sampling}

Raniganj coalfield is located in the Asansol and Durgapur subdivisions of Bardhaman district, West Bengal, India, which covers an area of $443.50 \mathrm{~km}^{2}$ and has a total coal reserve of 8552.85 million t. The reported coal reserves are 


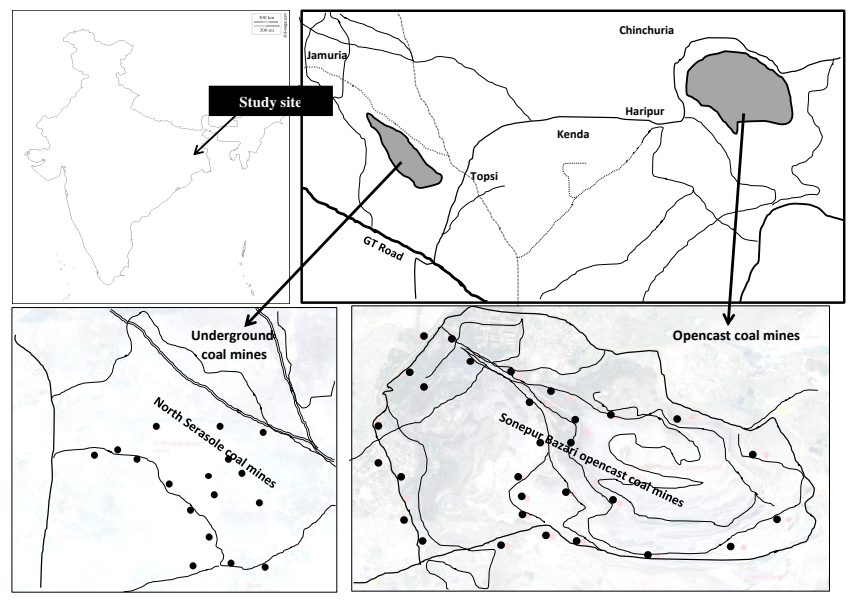

Figure 1. Location map of the study site.

29.72 billion $\mathrm{t}$, that make it the second largest coalfield in the country (in terms of reserves). Surface soil samples (0$0.15 \mathrm{~m}$ depth) were collected near an opencast mine (Sonepur Bazari) and underground mine (North Searsole of Raniganj coalfield. Most of the soils were from non-agricultural lands with no specific use. The sites were selected based on the availability of access roads in 2010 (Fig. 1). Altogether 32 samples were collected from the opencast mining (OCM) site and 17 samples were collected from the underground mining (UGM) site. A portion of the fresh soil samples was refrigerated for the analysis of soil biological parameters. The rest of the samples were air-dried, ground, and passed through a $2 \mathrm{~mm}$ sieve for further analysis.

\subsection{Soil analyses}

The methods described by Tandon (1993) and Baruah and Barthakur (1999) were used to determine the following soil properties: bulk density (soil core method), maximum waterholding capacity (by equilibrating the soil with water), porosity (derived from bulk density), $\mathrm{pH}$ and EC (electrical conductivity) of water $(1: 2.5$, soil / water ratio), soil organic carbon (SOC; by potassium dichromate oxidation), and loss on ignition (LOI). Active microbial biomass carbon (AMBC) was measured by the glucose nutrient-induced respiration method (Islam and Weil, 2000). Soil dehydrogenase activity was determined using the method of Klein et al. (1971). Phenol oxidase and peroxidase were measured with L-DOPA (L-3, 4 dihydroxyphenylalanine) as a substrate in an acetate buffer (Robertson et al., 1999). Basal soil respiration (BSR) was measured as the $\mathrm{CO}_{2}$ evolved from moist soil, adjusted to $60 \%$ water-holding capacity (WHC), over an incubation period of 10 days at $25 \pm 1{ }^{\circ} \mathrm{C}$, in the dark (Islam and Weil, 2000). Soil metabolic quotient (AMBC/SOC) was calculated. Specific maintenance respiration rates $\left(q \mathrm{CO}_{2}\right)$ were calculated as BSR per unit of active microbial biomass carbon (BSR/AMBC) (Anderson and Domsch, 1990; Islam and
Weil, 2000). Phosphatase enzyme (p-nitrophenyl phosphate method, colorimetry) and fluorescein diacetate hydrolase activity (FDA) of the soils were determined by the method described by Dick et al. (1996). For analysis of soil trace metal content, the soil samples were digested in a microwave digestion system (ETHOS, Milestone, Italy) as per the USEPA 3051A method (USEPA, 2007) and filtered. The metals in the filtrate were determined by ICP-OES (iCAP 6300Duo, Thermo Fisher Scientific, UK). For soil PAH analysis, samples were extracted using a $1: 1$ hexane: acetone mixture in a microwave extraction system as per the USEPA method 3546 (USEPA, 1995). The concentrated extract was analysed by the GC-MS system (Varian 450 GC and 240 MS) for 16 PAHs.

\subsection{Environmental soil quality indices}

Two types of indexing system were followed to derive the ESQI.

\subsubsection{Unscreened transformation}

ESQI $-1=\sum_{i=1}^{n} S_{i} / n$,

where $S$ denotes the score of the observed soil parameter, $n$ is the number of parameters included in the index.

\subsubsection{Principal component-based ESQI}

Principal component analysis (PCA) was used to select the appropriate properties and their weighing factors. PCs (principle components) with eigenvalue $\geq 1$ and which explained at least $5 \%$ of the variation of the data are examined (Sharma et al., 2005). Under a particular principal component, only the variables with high factor loadings were retained for indexing. High factor loadings were defined as having absolute values within $10 \%$ of the highest factor loading (Andrews et al., 2002a). When more than one variable was retained under a single PC, multivariate correlations were employed to determine whether the variables could be considered redundant and, therefore, eliminated from the ESQI (Andrews et al., 2002b). If the highly loaded factors were not correlated then each was considered important, and thus was retained in the ESQI. Among well-correlated variables, the variable with the highest factor loading (absolute value) was chosen for the ESQI. Each PC explained a certain amount of variation $(\%)$ in the total data set; this percentage provided the weight for variables chosen under a given PC. The final PCA-based ESQI equation is as follows:

$\mathrm{ESQI}-2=\sum_{i=1}^{n} W_{i} S_{i} / n$,

where $W$ is the PCA weighing factor of the soil properties selected by PCA, and $S$ is their respective scores. To convert the real values of the soil properties in to scores $(S)$ we used an equation that defined a sigmoidal type (Sinha et al., 2009), 
Table 1. Physical, chemical, and biological properties of soil in the opencast and underground mining site.

\begin{tabular}{|c|c|c|c|c|c|c|c|c|c|}
\hline \multirow[t]{2}{*}{ Soil parameters } & \multicolumn{4}{|c|}{ Underground mine $(n-17)$} & \multicolumn{4}{|c|}{ Opencast mine $(n-32)$} & \multirow[t]{2}{*}{$\mathrm{t}$ sig. } \\
\hline & Min & $\operatorname{Max}$ & Mean & SD & Min & $\operatorname{Max}$ & Mean & SD & \\
\hline $\mathrm{BD}$ & 1.15 & 1.59 & 1.36 & 0.128 & 1.20 & 1.55 & 1.41 & 0.096 & NS \\
\hline POR & 39.9 & 56.9 & 48.7 & 5.30 & 35.2 & 55.2 & 46.3 & 4.10 & NS \\
\hline WHC & 23.3 & 43.0 & 35.4 & 5.60 & 24.2 & 45.4 & 32.7 & 4.80 & NS \\
\hline $\mathrm{pH}$ & 4.90 & 7.80 & 6.37 & 0.818 & 4.88 & 8.58 & 6.28 & 0.890 & NS \\
\hline EC & 0.380 & 1.12 & 0.682 & 0.237 & 0.208 & 1.45 & 0.636 & 0.356 & NS \\
\hline SOC & 0.526 & 1.99 & 1.09 & 0.475 & 0.508 & 7.12 & 2.04 & 1.31 & 0.000 \\
\hline LOI & 4.36 & 16.1 & 9.17 & 3.45 & 11.4 & 24.9 & 15.9 & 2.44 & 0.000 \\
\hline DHA & 45.3 & 264 & 144 & 61.0 & 14.3 & 67.5 & 30.7 & 14.5 & 0.000 \\
\hline FDA & 3.34 & 14.0 & 8.53 & 3.23 & 1.12 & 15.5 & 5.80 & 3.48 & 0.009 \\
\hline AMBC & 23.3 & 186 & 96.2 & 35.9 & 20.3 & 175 & 92.7 & 45.7 & NS \\
\hline BSR & 498 & 812 & 675 & 90.9 & 456 & 861 & 675 & 93.3 & NS \\
\hline PHOX & 0.007 & 0.027 & 0.017 & 0.006 & 0.003 & 0.060 & 0.020 & 0.013 & NS \\
\hline POX & 0.001 & 0.027 & 0.010 & 0.006 & 0.005 & 0.051 & 0.023 & 0.012 & 0.000 \\
\hline ACP & 1.29 & 26.3 & 9.17 & 6.36 & 1.93 & 35.0 & 11.6 & 8.11 & NS \\
\hline AKP & 0.323 & 32.6 & 9.27 & 9.03 & 1.45 & 37.4 & 12.8 & 9.48 & NS \\
\hline AMBC/SOC & 0.003 & 0.017 & 0.009 & 0.004 & 0.001 & 0.024 & 0.006 & 0.006 & 0.041 \\
\hline BSR/AMBC & 3.65 & 27.8 & 8.44 & 5.39 & 3.76 & 20.1 & 10.3 & 7.40 & NS \\
\hline
\end{tabular}

$\mathrm{SD}$, standard deviation; $\mathrm{BD}$, bulk density $\left(\mathrm{Mg} \mathrm{m}^{-3}\right)$; POR, porosity (\%); WHC, water-holding capacity (\%); EC, electrical conductivity $\left(\mathrm{dS} \mathrm{m}^{-1}\right)$; SOC, Soil organic carbon (\%); LOI, loss on ignition (\%); DHA, dehydrogenase activity $\left(\mathrm{mg} \mathrm{TPF} \mathrm{kg}{ }^{-1} \mathrm{~h}^{-1}\right)$; FDA, fluorescein diacetate hydrolase activity (mg fluorescein $\left.\mathrm{kg}^{-1} \mathrm{~h}^{-1}\right)$; AMBC, active microbial biomass carbon $\left(\mathrm{mg} \mathrm{kg}^{-1}\right)$; BSR, basal soil respiration $\left(\mathrm{mg} \mathrm{CO}_{2}-\mathrm{C} \mathrm{kg}^{-1}\right.$ day $\left.{ }^{-1}\right)$; PHOX, phenol oxidase activity $\left(\mathrm{mM} \mathrm{g}^{-1} \mathrm{~h}^{-1}\right)$; $\mathrm{POX}$, peroxidase activity $\left(\mathrm{mM} \mathrm{g}^{-1} \mathrm{~h}^{-1}\right)$; ACP, acid phosphatase activity $\left(\mathrm{mg} \mathrm{PNP} \mathrm{kg}^{-1} \mathrm{~h}^{-1}\right)$; AKP, alkaline phosphatase activity (mg PNP kg ${ }^{-1} \mathrm{~h}^{-1}$ ); and NS, not significant at $P<0.05$.

with an asymptote tending to 1 and another tending to 0 .

$S=a /\left(1+\left(x / x_{0}\right)^{b}\right)$

where $x$ is the soil property value, a is the maximum score $(=1.00)$ of the soil property, $x_{0}$ is the mean value of each soil property, and $b$ is the value of the slope of the equation. The slope was -2.5 for the "more is better" curve and +2.5 for the "less is better" curve to obtain a sigmoidal curve tending to 1 for all the proposed properties.

\subsubsection{Statistical analysis}

The data were expressed as mean values and compared statistically by $t$ test; $P$ significance is presented. The ESQI was done using PCA (Andrews et al., 2002b). For computation, a SYSTAT-12 package was used.

\section{Results and discussion}

\subsection{Basic soil properties and biological parameters}

Soil bulk density, porosity, water-holding capacity, $\mathrm{pH}$, and electrical conductivity did not significantly differ between the OCM and UGM soils (Table 1). Mean soil organic carbon of the OCM soil was $2.04 \%$, whereas the SOC for UGM soil was $1.097 \%$. The SOC was almost $46 \%$ higher in OCM soil. In line with SOC, the loss on ignition was $65 \%$ higher in OCM soils. Deposition of fine coals on the soil surface could be the reason for the high SOC and LOI in these soils. Most of the OCM and UGM soils were black in color due to the significant coal contamination (Masto et al., 2011a, b).

Soil AMBC, BSR, phenol oxidase, and alkaline and acid phosphatase activities were not significantly affected between these two sites. Soil dehydrogenase $(+79 \%)$ and fluorescein $(+32 \%)$ activities were significantly higher in UGM soil, whereas peroxidase activity $(+57 \%)$ was higher in OCM soil. Soil trace elements may inactivate enzyme reactions by complexing the substrate, by reacting with proteinactive groups of enzyme-substrate, or by reacting with the enzyme-substrate complex or indirectly by altering the microbial community which synthesizes enzymes. Enzyme activity may either increase or decrease due to environmental contaminants. Trace metals affect microbial metabolism by altering the normal enzyme activities, particularly inhibition of a specific enzyme; the effects can be dramatic and systemic (Christensen et al., 1982). The presence of different trace metals and PAHs in coal-contaminated soils might have altered the soil enzyme activities (Masto et al., 2007b).

\subsection{Soil trace metals}

As, $\mathrm{Be}, \mathrm{Co}, \mathrm{Cr}, \mathrm{Cu}, \mathrm{Mn}, \mathrm{Ni}$, and $\mathrm{Pb}$ were significantly higher in OCM soil, whereas Cd was higher in UGM; and Zn was not significantly affected in these two soils (Table 2). Arsenic (As) content in the OCM soils ranged from 0.5 to 
Table 2. Soil trace metal contents in the opencast and underground mining site.

\begin{tabular}{|c|c|c|c|c|c|c|c|c|c|}
\hline \multirow[t]{2}{*}{ Trace metals $\left(\mathrm{mg} \mathrm{kg}^{-1}\right)$} & \multicolumn{4}{|c|}{ Underground mine $(n-17)$} & \multicolumn{4}{|c|}{ Opencast mine $(n-32)$} & \multirow[t]{2}{*}{$\mathrm{t}$ sig. } \\
\hline & Min & Max & Mean & SD & Min & Max & Mean & $\mathrm{SD}$ & \\
\hline As & 0.800 & 4.50 & 2.55 & 0.862 & 0.500 & 8.50 & 3.96 & 1.82 & 0.000 \\
\hline $\mathrm{Be}$ & 0.420 & 1.52 & 0.944 & 0.259 & 0.660 & 2.86 & 1.20 & 0.500 & 0.021 \\
\hline $\mathrm{Cd}$ & 0.001 & 0.220 & 0.06 & 0.070 & 0.001 & 0.100 & 0.012 & 0.026 & 0.006 \\
\hline Co & 4.60 & 25.1 & 14.5 & 5.85 & 7.90 & 54.2 & 22.0 & 10.8 & 0.002 \\
\hline $\mathrm{Cr}$ & 32.5 & 93.5 & 64.3 & 16.5 & 50.0 & 187 & 97.5 & 34.4 & 0.000 \\
\hline $\mathrm{Cu}$ & 11.3 & 41.0 & 21.9 & 8.57 & 14.5 & 43.0 & 27.1 & 6.91 & 0.041 \\
\hline $\mathrm{Mn}$ & 100 & 824 & 436 & 229 & 169 & 5494 & 947 & 918 & 0.005 \\
\hline $\mathrm{Ni}$ & 12.7 & 41.2 & 27.5 & 8.55 & 18.9 & 87.6 & 33.9 & 14.4 & 0.056 \\
\hline $\mathrm{Pb}$ & 10.7 & 26.9 & 17.4 & 4.42 & 11.6 & 73.7 & 27.3 & 14.5 & 0.000 \\
\hline $\mathrm{Zn}$ & 21.2 & 89.0 & 47.8 & 21.5 & 24.8 & 84.3 & 46.8 & 15.8 & NS \\
\hline
\end{tabular}

NS, not significant at $P<0.05$.

$8.5 \mathrm{mg} \mathrm{kg}^{-1}$ with a mean content of $3.97 \mathrm{mg} \mathrm{kg}^{-1}$, however the mean As content in UGM was $2.55 \mathrm{mg} \mathrm{kg}^{-1}$. Other elements like $\mathrm{Be}(+28 \%)$, Co $(+52 \%), \mathrm{Cr}(+51 \%), \mathrm{Cu}$ $(+24 \%), \mathrm{Mn}(+54 \%)$ and $\mathrm{Ni}(+23 \%)$ were also significantly higher in OCM than the UGM soils. Most of the elements are enriched in OCM soil probably due to the relatively higher land disturbances and coal dispersion in the OCM site. Among the elements, the content of $\mathrm{Co}$ and Cr was $>50 \%$ higher in OCM soils. Mine fire can be the source of cobalt in soils as coal combustion generates Co as fine particulate matter (Srivastava and Jain, 2007). The rate of release of $\mathrm{Cr}$ into the global atmosphere from coal combustion is estimated to be in the order of a few thousands of tons per year (USEPA, 1990). The mean Cr content of coals is only $20 \mathrm{mg} \mathrm{kg}^{-1}$ worldwide (Huggins et al., 2000). Cd was slightly higher in the UGM soils. In Yatagan, Turkey, Yapici et al. (2006) reported that exploration of coal minerals contributed to $\mathrm{Cd}$ concentration in the local biota. The $\mathrm{Zn}$ content was not affected significantly between the OCM and UGM sites, since the $\mathrm{Zn}$ in the soil is probably originated from vehicular activities. Tyre treads and tyre dust contain significant amounts of $\mathrm{Zn}$ (Apeagyei et al., 2011; Dore et al., 2014), thereby it is likely that the contamination of both OCM and UGM soils with Zn is from vehicular activities. The trace elements content in the local coal samples could be arranged in the order: $\mathrm{Zn}$ $\left(28.6 \mathrm{mg} \mathrm{kg}^{-1}\right)>\mathrm{Ni}\left(3.7 \mathrm{mg} \mathrm{kg}^{-1}\right)>\mathrm{Cu}\left(1.8 \mathrm{mg} \mathrm{kg}^{-1}\right)>\mathrm{As}$ $\left(0.5 \mathrm{mg} \mathrm{kg}^{-1}\right)>\mathrm{Cd}\left(0.1 \mathrm{mg} \mathrm{kg}^{-1}\right)>\mathrm{Cr}\left(0.08 \mathrm{mg} \mathrm{kg}^{-1}\right)$. The content of $\mathrm{Pb}, \mathrm{Be}$, and $\mathrm{Co}$ in Raniganj coalfield was below the detection limits. Based on the relative abundance in local coals, it appears that $\mathrm{Ni}$ in soil might have originated from the coal and the rest might have originated from automobiles and other anthropogenic sources. The contribution of $\mathrm{Zn}$ from local coal is also possible.

\subsection{Soil PAHs}

Among the soil PAHs, acenapththylene and phenanthrene were not significantly affected between OCM and UGM soils (Table 3). Naphthalene $(+26 \%)$, fluorene $(+66 \%)$, anthracene $(+43 \%)$, fluoranthene $(+44 \%)$, pyrene $(+52 \%)$, benz(a)anthracene $(+41 \%)$, chrysene $(+50 \%)$, benzo(b)fluoranthene $(+66 \%)$, benzo(k)fluoranthene $(+69 \%)$, benzo(a)pyrene $(+62 \%)$, and total PAHs $(+24.3 \%)$ were significantly higher in UGM soils. Acenaphthene $(+43 \%)$, benzo $(g, h, i)$ perylene $(+89 \%)$, and dibenz(a,h)anthracene $(+94 \%)$ were significantly higher in OCM soils. PAH distribution in three different coal mines of China revealed that naphthalene and acenaphthalene are the most abundant species in all three of the sampling sites (Wang et al., 2010). In general, the PAHs contents were higher in UGM soils probably due to the natural coal burning at these sites. The said coal mine has experienced mine fires, and mining operations were closed for quite a few years. Tsibart et al. (2014) observed higher PAHs content in soils affected by mine fire. Maximum concentrations of a total of 14 PAHs were detected in charred peat horizons (up to $330 \mathrm{mg} \mathrm{kg}^{-1}$ ) and in post-fire incipient $\mathrm{O}$ horizons (up to $180 \mathrm{mg} \mathrm{kg}^{-1}$ ), but the high-molecular-weight PAHs (benz(ghi)perylene, benz(a)pyrene, benz(k)fluoranthene) were revealed only in charry peat horizons. During coal burning the organic compounds in the coal are partially cracked to smaller and unstable fragments. These fragments, mainly highly reactive free radicals with a very short average lifetime, lead to more stable PAH formation through recombination reactions (Mastral and Callén, 2000; Schwarzbauer, 2006; Emsbo-Mattingly and Stout, 2011). Further, fluoranthene and pyrene are enriched in UGM soils, and are commonly considered as typical pyrogenic products derived from high temperature condensation of lower molecular weight aromatic compounds (Li et al., 2010; Soclo et al., 2000). PAHs are emitted in the gas and solid phases. Both these PAHs can travel in the atmosphere 
Table 3. Soil PAH contents in the opencast and underground mining site.

\begin{tabular}{|c|c|c|c|c|c|c|c|c|c|}
\hline \multirow{2}{*}{ PAHs (mg kg ${ }^{-1}$ ) } & \multicolumn{4}{|c|}{ Underground mine $(n-17)$} & \multicolumn{4}{|c|}{ Opencast mine $(n-32)$} & \multirow[t]{2}{*}{$\mathrm{t} \operatorname{sig}$} \\
\hline & Min & $\operatorname{Max}$ & Mean & $\mathrm{SD}$ & Min & Max & Mean & SD & \\
\hline Naphthalene & 0.052 & 0.346 & 0.173 & 0.082 & 0.049 & 0.300 & 0.128 & 0.078 & 0.070 \\
\hline Acenapththylene & 0.200 & 2.05 & 0.842 & 0.564 & 0.129 & 1.90 & 0.650 & 0.460 & NS \\
\hline Acenaphthene & 0.147 & 3.20 & 1.68 & 0.863 & 0.496 & 8.40 & 2.952 & 1.89 & 0.002 \\
\hline Fluorene & 0.120 & 2.32 & 0.845 & 0.697 & 0.080 & 0.978 & 0.287 & 0.206 & 0.004 \\
\hline Phenanthrene & 0.373 & 4.50 & 1.80 & 1.17 & 0.149 & 2.80 & 1.20 & 0.728 & NS \\
\hline Anthracene & 0.183 & 2.40 & 1.56 & 0.709 & 0.141 & 2.90 & 0.887 & 0.650 & 0.002 \\
\hline Fluoranthene & 0.191 & 2.41 & 1.31 & 0.653 & 0.125 & 2.17 & 0.730 & 0.528 & 0.003 \\
\hline Pyrene & 0.204 & 2.22 & 1.39 & 0.663 & 0.128 & 1.40 & 0.668 & 0.321 & 0.000 \\
\hline Benz(a)anthracene & 0.167 & 1.51 & 0.839 & 0.479 & 0.124 & 1.34 & 0.496 & 0.278 & 0.012 \\
\hline Chrysene & 0.224 & 2.00 & 1.27 & 0.559 & 0.136 & 1.93 & 0.631 & 0.454 & 0.000 \\
\hline Benzo(b)fluoranthene & 0.478 & 4.20 & 2.93 & 1.06 & 0.286 & 1.80 & 1.00 & 0.460 & 0.000 \\
\hline Benzo(k)fluoranthene & 0.222 & 2.89 & 1.27 & 0.669 & 0.145 & 0.935 & 0.388 & 0.175 & 0.000 \\
\hline Benzo(a)pyrene & 0.231 & 3.13 & 1.54 & 0.836 & 0.132 & 1.40 & 0.586 & 0.366 & 0.000 \\
\hline Benzo(g,h,i)perylene & 0.079 & 0.203 & 0.128 & 0.032 & 0.332 & 1.99 & 1.18 & 0.365 & 0.000 \\
\hline Dibenzo(a,h)anthracene & 0.027 & 0.145 & 0.065 & 0.029 & 0.365 & 2.25 & 1.07 & 0.429 & 0.000 \\
\hline Indeno( $1,2,3, \mathrm{~cd})$ pyrene & 0.021 & 0.186 & 0.108 & 0.037 & 0.187 & 1.35 & 0.58 & 0.327 & 0.000 \\
\hline$\sum$ PAHs & 2.92 & 33.7 & 17.8 & 9.11 & 3.00 & 33.8 & 13.4 & 7.72 & 0.007 \\
\hline
\end{tabular}

NS, not significant at $P<0.05$.

and settle on soil, water bodies, and other environmental media (Peng et al., 2011). Natural mine fires as well as the domestic use of coal for cooking in the UGM site might have contributed to elevated PAHs content in the UGM soils. Natural coal fires were not reported in the OCM sites of the present study. Domestic coal burning is also not present in OCM site as the OCM is away from residential area.

\subsection{Environmental soil quality index}

Individual soil parameter values were normalized on a scale from 0 to 1 , based on two types of curve: "more is better" (POR, WHC, pH, SOC, DHA, FDA, AMBC, BSR, PHOH, $\mathrm{POH}, \mathrm{ACP}, \mathrm{AKP}, \mathrm{AMBC} / \mathrm{SOC})$; and "less is better" (BD, $\mathrm{EC}, \mathrm{LOI}$, trace metals, PAHs, BSR/AMBC). "More is better" was designated for $\mathrm{pH}$, as the mean $\mathrm{pH}$ in both these soils was < 7.0. "Less is better" was designated for loss on ignition, as it indicates the quantum of coal contamination. The calculated scores were integrated in to ESQI by two indexing methods as below.

\subsubsection{Unscreened transformation (ESQI-1)}

The index is the summation of the scores obtained by individual indicators, divided by the total number of indicators; here all the soil parameters have equal weightage. ESQI-1 ranged from 0.478 to 0.595 in UGM and 0.383 to 0.603 in OCM. The ESQI was further segregated into physical, chemical, biological, trace metal, and PAH qualities (Eq. 4) and the data are presented in Fig. 2a. The physical (0.104 vs. 0.097), chemical (0.109 vs. 0.099), biological (0.098 vs. 0.084), and trace metal ( 0.126 vs. 0.107$)$ quality was better in UGM than OCM, however, it was reversed for PAHs (0.103 vs. 0.124). Thus the overall mean ESQI was 0.539 and 0.511 for UGM and OCM, respectively. These findings highlight the importance of inclusion of PAHs in soil quality assessment. In many of the past soil quality studies PAHs were not included; the mean ESQI without PAHs would be overestimating the quality of UGM soils.

$$
\begin{aligned}
& \text { ESQI }-1=0.2 S_{\text {Physical }}+0.2 S_{\text {Chemical }}+0.2 S_{\text {Biological }} \\
& +0.2 S_{\text {Heavy metals }}+0.2 S_{\text {PAHs }}
\end{aligned}
$$

A similar kind of unscreened index was developed by Masto et al. (2008a, b) and found that the chemical parameters contribute the most to the SQI, followed by biological and physical properties. The physical quality was the same in all of the soil treatments; chemical and biological qualities were higher in soils receiving organic manure along with chemical fertilizer. In the present study the physical, chemical, and biological properties did not vary much between the UGM and OCM, but the soil quality scores for trace metals and PAHs differed significantly. The major difference in soil quality for agricultural and urban/industrial soils lies here. For agricultural soils, the soil quality is determined by soil $\mathrm{pH}$, organic carbon, basic physical properties, plant nutrients and some biological parameters. But for industrial soils, the potentially toxic substances contribute to soil quality. Thus further extension of ESQI to human health risks through specific exposure pathways is needed (Zornoza et al., 2015). 

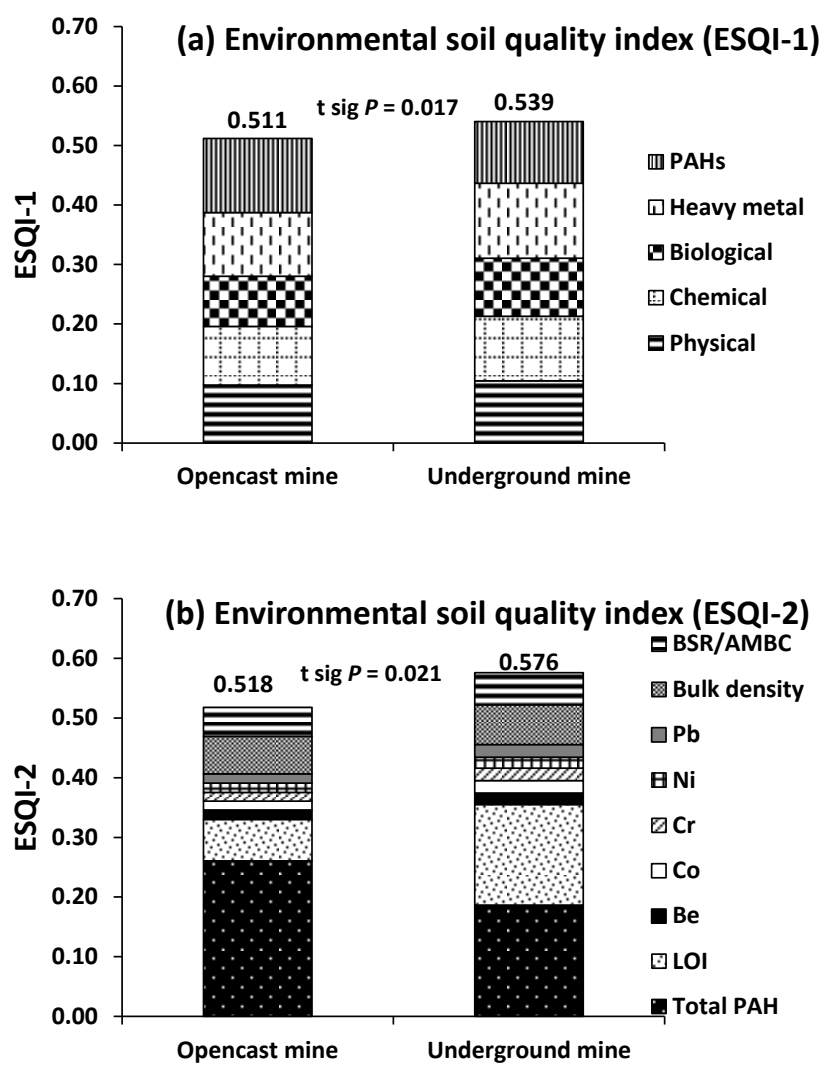

Figure 2. Environmental soil quality index of opencast and underground mine soils by (a) unscreened transformations (ESQI-1), and (b) principal component analysis-based index (ESQI-2).

\subsubsection{Principal component analysis-based index (ESQI-2)}

All the soil variables were included for principal component analysis. The first five PCs had eigenvalues $>1.00$ (Table 4). The highly loaded variable under PC-1 was total PAHs and was included in the ESQI. Likewise in PC-2, LOI, dibenzo(a,h)anthracene, indeno(1,2,3,c,d)pyrene, and benzo(g,h,i)perylene were highly loaded. As these parameters are highly correlated $(r>0.700)$ among themselves and the total PAHs were already included in the ESQI, only LOI from PC-2 was included in the index. Similarly, Be, Co, $\mathrm{Cr}, \mathrm{Ni}$, and $\mathrm{Pb}$ were included from $\mathrm{PC}-3$; all these elements were correlated among themselves, therefore the weight corresponding to $\mathrm{PC}-3$ was equally divided among these elements. BD, POR, and WHC were highly loaded from PC4 , and these parameters were correlated among themselves; only BD was selected for the ESQI. Similarly, from PC-5, BSR/AMBC was included in the ESQI. Weights for selected variables were determined by the percent variation in the data set explained by the five PCs. The final normalized PCA- based soil quality equation is

$$
\begin{aligned}
& \text { ESQI }-2=0.439 S_{\text {total PAHs }}+0.195 S_{\mathrm{LOI}}+0.031 S_{\mathrm{Be}} \\
& +0.031 S_{\mathrm{Co}}+0.031 S_{\mathrm{Cr}}+0.031 S_{\mathrm{Ni}}+0.031 S_{\mathrm{Pb}} \\
& +0.128 S_{\mathrm{BD}}+0.084 S_{\mathrm{BSR} / \mathrm{AMBC}}
\end{aligned}
$$

This is probably one of the first studies where total PAHs has been used as a soil quality indicator. In line with PAHs, the LOI was also included in the ESQI. The LOI could be an indirect measure of the coal contamination in the soils; the LOI observed in the soils is much higher than the normal soils. As coal is an organic matter, it contributes to soil LOI and PAHs. In our study, higher organic matter is indicative of the quantum of coal contamination; the lower the LOI, the better the soil quality. However, for agricultural soils, a decrease in organic matter/carbon indicates a decline in soil quality (Bruun et al., 2015). The soil PAH is very important from a contamination and human exposure point of view. A PAH profile of UK soils indicates that benzo[a]pyrene is a good surrogate marker, being ubiquitous in sites contaminated with PAHs and providing a consistent indicator of the number of PAHs in contaminated soil (HPA, 2010). Fluoranthene is suggested as a complementary indicator to benzo(a)pyrene (Bostrom et al., 2002). Trace metals are ubiquitous pollutants. Coal has also been reported as one of the sources of trace metal pollutants, especially $\mathrm{Cr}, \mathrm{Ni}$, and Co (Masto et al., 2007b), as some of these elements are enriched in the coal. The bulk density is an important parameter which affects the soil productivity of the coal-mined land because it indicates the suitability of the soil for root proliferation, water-holding capacity, and long-term nutrient availability. It is found to affect the entire biological reclamation process by influencing moisture retention capacity, and porosity. The ratio BSR / AMBC is most appropriately used as an index of adversity of environmental conditions for the soil microflora and has valuable applications as a relative measure of how efficiently the soil microbial biomass is utilizing carbon sources, and the degree of substrate limitation for the soil microorganisms (Wardle and Ghani, 1995). Soil microorganisms divert more energy from growth to maintenance as stress increases and thus the ratio of respired $\mathrm{C}$ to biomass $\mathrm{C}$ can be a much more sensitive indicator of stress. The BSR / MBC ratio indicates the carbon turnover rates in the soils. The importance of soil organic carbon in improving the overall soil quality has been widely reported (Debasish et al., 2014; Fialho and Zinn, 2014; Lozano-García and Parras-Alcántara, 2014). Paz-Ferreiro and Fu (2014) reviewed the limitations of using the biochemical, microbiological, and biological properties of soil for soil quality evaluation. The ESQI-2 obtained using the PCA is presented in Fig. 2b, where the contribution of each soil indicator parameter on calculated ESQI is also shown, which gives an insight into the cause for the measured ESQI. The ESQI is higher in UGM $(+10.1 \%)$ than OCM soil. Total PAHs and LOI are the 
Table 4. Principal component analysis of soil parameters in opencast and underground mining sites.

\begin{tabular}{|c|c|c|c|c|c|}
\hline \multirow[b]{2}{*}{ Principal components } & \multicolumn{5}{|c|}{ Rotated compound matrix } \\
\hline & PC-1 & PC-2 & PC-3 & PC-4 & PC-5 \\
\hline$\%$ Variance & 27.00 & 11.98 & 9.410 & 7.936 & 5.270 \\
\hline$\%$ Cumulative eigenvectors & 27.00 & 38.99 & 48.40 & 56.33 & 61.60 \\
\hline $\mathrm{BD}$ & 0.032 & 0.098 & 0.03 & 0.951 & 0.028 \\
\hline POR & 0.016 & -0.126 & -0.032 & 0.943 & -0.014 \\
\hline WHC & 0.044 & -0.049 & 0.123 & 0.855 & 0.202 \\
\hline $\mathrm{pH}$ & 0.067 & 0.031 & 0.076 & 0.233 & -0.070 \\
\hline $\mathrm{EC}$ & -0.010 & 0.029 & -0.230 & 0.365 & -0.042 \\
\hline SOC & 0.024 & 0.232 & 0.149 & 0.182 & -0.048 \\
\hline LOI & -0.362 & 0.790 & 0.157 & 0.003 & -0.040 \\
\hline DHA & 0.219 & $\overline{-0.705}$ & -0.206 & 0.239 & -0.049 \\
\hline FDA & 0.134 & -0.319 & -0.163 & 0.170 & 0.127 \\
\hline AMBC & 0.104 & 0.013 & 0.200 & 0.043 & $\mathbf{0 . 8 3 3}$ \\
\hline BSR & -0.094 & 0.024 & -0.082 & 0.076 & 0.138 \\
\hline PHOX & -0.152 & 0.067 & 0.120 & -0.155 & 0.140 \\
\hline $\mathrm{ACP}$ & 0.062 & 0.237 & -0.198 & 0.023 & -0.527 \\
\hline AKP & -0.199 & 0.089 & -0.031 & -0.096 & 0.030 \\
\hline AMBC/SOC & -0.075 & -0.189 & 0.004 & 0.045 & 0.642 \\
\hline BSR/AMBC & -0.113 & 0.038 & -0.161 & -0.025 & $-\underline{0.836}$ \\
\hline As & -0.171 & 0.225 & 0.369 & -0.288 & $\overline{0.030}$ \\
\hline $\mathrm{Be}$ & 0.021 & 0.158 & 0.870 & 0.135 & 0.084 \\
\hline $\mathrm{Cd}$ & 0.162 & -0.297 & $\overline{-0.154}$ & 0.419 & -0.088 \\
\hline $\mathrm{Co}$ & -0.054 & 0.169 & 0.845 & -0.089 & 0.008 \\
\hline $\mathrm{Cr}$ & -0.217 & 0.187 & $\overline{0.836}$ & -0.087 & 0.117 \\
\hline $\mathrm{Cu}$ & -0.117 & 0.260 & 0.701 & 0.456 & 0.122 \\
\hline $\mathrm{Mn}$ & -0.129 & 0.169 & 0.669 & -0.119 & 0.086 \\
\hline $\mathrm{Ni}$ & -0.176 & 0.039 & 0.848 & 0.056 & 0.142 \\
\hline $\mathrm{Pb}$ & -0.055 & 0.156 & $\overline{0.894}$ & -0.170 & 0.031 \\
\hline $\mathrm{Zn}$ & 0.181 & 0.078 & 0.491 & 0.478 & 0.092 \\
\hline POX & -0.111 & 0.471 & 0.151 & 0.002 & 0.249 \\
\hline Naphthalene & 0.683 & -0.062 & -0.131 & 0.193 & 0.003 \\
\hline Acenapththylene & 0.782 & 0.094 & -0.119 & 0.095 & 0.144 \\
\hline Acenaphthene & 0.595 & 0.656 & -0.022 & -0.042 & -0.052 \\
\hline Fluorene & 0.622 & -0.327 & -0.216 & 0.048 & 0.193 \\
\hline Phenanthrene & 0.812 & -0.106 & 0.033 & 0.053 & -0.156 \\
\hline Anthracene & 0.851 & -0.162 & -0.017 & -0.053 & 0.033 \\
\hline Fluoranthene & 0.812 & -0.199 & -0.013 & 0.000 & 0.077 \\
\hline Pyrene & 0.686 & -0.461 & -0.145 & -0.025 & -0.020 \\
\hline Benzaanthracene & 0.570 & -0.313 & 0.086 & 0.074 & 0.041 \\
\hline Chrysene & 0.708 & -0.336 & -0.168 & 0.000 & -0.179 \\
\hline Benzo(b)fluoranthene & 0.553 & -0.648 & -0.166 & -0.062 & 0.155 \\
\hline Benzo(k)fluoranthene & 0.437 & -0.617 & -0.176 & -0.088 & 0.160 \\
\hline Benzo(a)pyrene & 0.526 & -0.495 & -0.132 & 0.047 & 0.186 \\
\hline $\operatorname{Benzo}(\mathrm{g}, \mathrm{h}, \mathrm{i})$ perylene & -0.148 & 0.874 & 0.186 & -0.077 & -0.147 \\
\hline Dibenzo(a,h)anthracene & -0.118 & 0.855 & 0.193 & -0.039 & 0.081 \\
\hline Indeno( $1,2,3, \mathrm{c}, \mathrm{d})$ pyrene & -0.079 & 0.787 & 0.168 & -0.230 & -0.007 \\
\hline Total PAHs & 0.976 & -0.020 & -0.078 & -0.033 & 0.047 \\
\hline
\end{tabular}

Boldface eigenvalues correspond to the PCs examined for the index; boldface factor loadings are considered highly weighed; bold-underlined factors correspond to the indicators included in the index. 
limiting parameters in UGM $(-39.6 \%)$ and OCM $(-143 \%)$ soils, respectively. In general, the UGM has comparatively fewer environmental impacts than opencast mining. As underground mining operations take place below ground, they generally do not create as much air pollution; contribute less to groundwater, surface water, and soil pollution; and are not as visually intrusive. Similar soil quality studies on mining area showed that reclamation of mine soil through plantation could improve the SQI score (Asensio et al., 2013). The ESQI-2 is also heavily weighted by the potentially toxic substances like PAHs and trace metals than the routine soil quality indicators generally used for agricultural soils. Overall, this study indicates the need for inclusion of human health issues in soil quality assessments.

\section{Conclusions}

Unscreened transformation and PCA-based index showed that the underground mine soil has better soil quality values $(0.539$ and 0.576$)$ than the opencast mines $(0.511$ and 0.518). Based on principal component analysis total PAHs, loss on ignition, bulk density, $\mathrm{Be}, \mathrm{Co}, \mathrm{Cr}, \mathrm{Ni}, \mathrm{Pb}$, and microbial quotient (respiration: microbial biomass ratio) were found to be the most critical soil quality indicators. For the first time, total soil PAH has emerged as an indicator of soil quality and it is pertinent to reinforce the fact that the index is being applied to coal-contaminated soils. Another interesting finding is the loss on ignition (an indirect measure of soil organic matter) has been used as an indicator with a negative score ("less is better"). Again here, it is only applicable for coal-contaminated soils. The proposed equation as an environmental soil quality index could be valid for establishing the degree of degradation of coal-contaminated soils as a function of the physical, chemical, and biological parameters of the soil, and trace metals and PAHs in the soil. The soil quality index could be refined further by including parameters related to human exposure risks based on specific exposure pathways.

Acknowledgements. We express our thanks to the Director of the CSIR-Central Institute of Mining and Fuel Research, Dhanbad, India, for supporting this publication. The financial support availed from the Network Project NWP-0017 (11th Five Year Plan), Council of Scientific and Industrial Research (CSIR), and the Ministry of Science and Technology, government of India, is greatly acknowledged.

Edited by: A. Cerdà

\section{References}

Anderson, T. H. and Domsch, K. H.: Application of ecophysiological quotients $\left(\mathrm{qCO}_{2}\right.$ and $\left.\mathrm{qD}\right)$ on microbial biomasses from soils of different cropping histories, Soil Biol. Biochem., 22, 251-255, 1990.

Andrews, S. S., Karlen, D. L., and Mitchell, J. P.: A comparison of soil quality indexing methods for vegetable production systems in Northern California, Agr. Ecosyst. Environ., 90, 25-45, doi:10.1016/S0167-8809(01)00174-8, 2002a.

Andrews, S. S., Mitchell, J. P., Mancinelli, R., Karlen, D. L., Hartz, T. K., Horwath, W. R., Pettygrove, G. S., Scow, K. M., and Munk, D. S.: On-farm assessment of soil quality in California's Central Valley, Agron. J., 94, 12-23, doi:10.2134/agronj2002.1200, 2002b.

Apeagyei, E., Bank, M. S., and Spengler, J. D.: Distribution of heavy metals in road dust along an urban-rural gradient in Massachusetts, Atmos. Environ., 45, 2310-2323, doi:10.1016/j.atmosenv.2010.11.015, 2011.

Asensio, V., Guala, S. D., Vega, F. A., and Covelo, E. F.: A soil quality index for reclaimed mine soils, Environ. Toxicol. Chem. 32, 2240-2248, doi:10.1002/etc.2315, 2013.

Baruah, T. C. and Barthakur, H. P.: A Text Book of Soil Analysis, Vikas Publishing House Pvt. Ltd., New Delhi, 1999.

Bostrom, C. E., Gerde, P., Hanberg, A., Jernstrom, B., Johansson, C., Kyrklund, T., Rannug, A., Tornqvist, M., Victorin, K., and Westerholm, R.: Cancer risk assessment, indicators, and guidelines for polycyclic aromatic hydrocarbons in the ambient air, Environ. Health Persp., 110, 451-488, 2002.

Brevik, E. C., Cerdà, A., Mataix-Solera, J., Pereg, L., Quinton, J. N., Six, J., and Van Oost, K.: The interdisciplinary nature of SOIL, SOIL, 1, 117-129, doi:10.5194/soil-1-117-2015, 2015.

Bruun, T. B., Elberling, B., de Neergaard, A., and Magid, J.: Organic Carbon Dynamics in Different Soil Types After Conversion of Forest to Agriculture, Land Degrad. Dev., 26, 272-283, doi:10.1002/ldr.2205, 2015.

Chaudhuri, S., McDonald, L. M., Skousen, J., and Pena-Yewtukhiw, E. M.: Soil Organic Carbon Molecular Properties: Effects of Time Since Reclamation in a Minesoil Chronosequence, Land Degrad. Dev., 26, 237-248, doi:10.1002/ldr.2202, 2015.

Chaulya, S. K.: Assessment and management of air quality for an opencast coal mining area, J. Environ. Manage., 70, 1-14, doi:10.1016/j.jenvman.2003.09.018, 2004.

Christensen, G. M., Olson, D., and Riedel, B.: Chemical effects on the activity of eight enzymes: a review and a discussion relevant to environmental monitoring, Environ. Res., 29, 247-255, doi:10.1016/0013-9351(82)90026-3, 1982.

Das, A., Ghosh, P. K., Lal, R., Saha, R., and Ngachan, S.: Soil quality effect of conservation practices in maize-rapeseed cropping system in Eastern Himalaya, Land Degrad. Dev., doi:10.1002/ldr.2325, in press, 2014.

Debasish, S., Kukal, S. S., and Bawa, S. S.: Soil organic carbon stock and fractions in relation to land use and soil depth in the degraded Shiwaliks Hills of Lower Himalayas, Land Degrad. Dev., 25, 407-416, doi:10.1002/ldr.2151, 2014.

Dick, R. P., Breakwell, D. P., and Turco, R. F.: Soil enzyme activities and biodiversity measurements as integrative microbiological indicators, in: Methods for Assessing Soil Quality, edited by: Doran, J. and Jones, A., SSSA, Madison, WI, USA, Spec. Publ. no. 49, 247-271, 1996 
Dore, A. J., Hallsworth, S., McDonald, A. G., Werner, M., Kryza, M., Abbot, J., Nemitz, E., Dore, C. J., Malcolm, H., Vieno, M., Reis, S., and Fowler, D.: Quantifying missing annual emission sources of heavy metals in the United Kingdom with an atmospheric transport model, Sci. Total Environ., 479-480, 171-180, 2014.

Emsbo-Mattingly, S. D. and Stout, S. A.: Semivolatile hydrocarbon residues of coal and coal tar, in: Coal and Peat Fires: A Global Perspective, edited by: Stracher, G. B., Prakash, A., and Sokol, E. V., vol. 1, Elsevier, 173-208, 2011.

Fialho, R. C. and Zinn, Y. L.: Changes in soil organic carbon under eucalyptus plantations in Brazil: a comparative analysis, Land Degrad. Dev., 25, 428-437, doi:10.1002/ldr.2158, 2014.

Ghose, M.: Generation and quantification of hazardous dusts from coal mining in the Indian context, Environ. Monit. Assess., 130, 35-45, doi:10.1007/s10661-006-9451-y, 2007.

Guo, S.-L., Li, Q., Li, X.-J., Zhao, Y.-L., and Wang, X.-G.: Effects of mushroom waste on improvement of reclaimed soil quality in coal mining areas, J. Coal Sci Eng China, 19, 237-242, 10.1007/s12404-013-0220-6, 2013.

Guo, S.-L., Li, Q., Li, X.-J., Zhao, Y.-L., and Wang, X.-G.: Effects of mushroom waste on improvement of reclaimed soil quality in coal mining areas, J. Coal Sci. Eng. China, 19, 237-242, doi:10.1007/s12404-013-0220-6, 2013.

Haigh, M., Reed, H., Flege, A., D’Aucourt, M., Plamping, K., Cullis, M., Woodruffe, P., Sawyer, S., Panhuis, W., Wilding, G., Farrugia, F., and Powell, S.: Effect of Planting Method on the Growth of Alnus glutinosa and Quercus petraea in Compacted Opencast Coal-Mine Spoils, South Wales, Land Degrad. Dev., 26, 227-236, doi:10.1002/ldr.2201, 2015.

HPA Contaminated Land Information Sheet: Risk Assessment Approaches for Polycyclic Aromatic Hydrocarbons (PAHs), available at: http://webarchive.nationalarchives.gov. uk/20140714084352/http://www.hpa.org.uk/webc/hpawebfile/ hpaweb_c/1287147342113 (last access: 30 December 2014), 2010.

Huggins, F. E., Shah, N., Huffman, G. P., Kolker, A., Crowley, S., Palmer, C. A., and Finkelman, R. B.: Mode of occurrence of chromium in four US coals, Fuel Process. Technol., 63, 79-92, doi:10.1016/S0378-3820(99)00090-9, 2000.

Islam, K. R. and Weil, R. R.: Land use effects on soil quality in a tropical forest ecosystem of Bangladesh, Agr. Ecosyst. Environ., 79, 9-16, 2000.

Jarup, L.: Hazard of heavy metal contamination, Brazilian Medical Bulletin, 68, 167-182, 2003.

Keesstra, S. D., Bruijnzeel, L. A., and van Huissteden, J.: Mesoscale catchment sediment budgets: combining field surveys and modeling in the Dragonja catchment, southwest Slovenia, Earth Surf. Proc. Land., 34, 1547-1561, doi:10.1002/esp.1846, 2009.

Keesstra, S. D.: Impact of natural reforestation on floodplain sedimentation in the Dragonja basin, SW Slovenia, Earth Surf. Proc. Land., 32, 49-65, doi:10.1002/esp.1360, 2007.

Klein, D. A., Loh, T. C., and Goulding, R. L.: A rapid procedure to evaluate the dehydrogenase activity of soils low in organic matter, Soil Biol. Biochem., 3, 385-387, doi:10.1016/00380717(71)90049-6, 1971.

Li, H., Chen, J., Wu, W., and Piao, X.: Distribution of polycyclic aromatic hydrocarbons in different size fractions of soil from a coke oven plant and its relationship to or- ganic carbon content, J. Hazard. Mater., 176, 729-734, doi:10.1016/j.jhazmat.2009.11.095, 2010.

Lozano-García, B. and Parras-Alcántara, L.: Variation in soil organic carbon and nitrogen stocks along a toposequence in a traditional mediterranean olive grove, Land Degrad. Dev., 25, 297 304, doi:10.1002/ldr.2284, 2014.

Masto, R. E., Chhonkar, P. K., Singh, D., and Patra, A. K.: Soil quality response to long-term nutrient and crop management on a semi-arid Inceptisol, Agr. Ecosyst. Environ., 118, 130-142, doi:10.1016/j.agee.2006.05.008, 2007a.

Masto, R. E., Ram, L. C., Selvi, V. A., Jha, S. K., and Srivastava, N. K.: Soil contamination and human health risks in coal mining environs, International Conference on MSECCMI New Delhi, 1921 November 2007, 257-265, 2007b.

Masto, R. E., Chhonkar, P. K., Purakayastha, T. J., Patra, A. K., and Singh, D.: Soil quality indices for evaluation of long-term land use and soil management practices in semi-arid sub-tropical India, Land Degrad. Dev., 19, 516-529, doi:10.1002/ldr.857, 2008a.

Masto, R. E., Chhonkar, P. K., Singh, D., and Patra, A. K.: Alternative soil quality indices for evaluating the effect of intensive cropping, fertilisation and manuring for 31 years in the semi-arid soils of India, Environ. Monit. Assess., 136, 419-435, 2008b.

Masto, R. E, Ram, L. C., George, J., Selvi, V. A., Sinha, A. K., Verma, S. K., Rout, T. K., Priyadarshini, and Prabal, P.: Impacts of opencast coal mine and mine fire on the trace elements' content of the surrounding soil vis-à-vis human health risk', Toxicol. Environ. Chem., 99, 223-237, 2011a.

Masto, R. E., Ram, L. C., Shandilya, P. R., Sinha, S., George, J., and Selvi, V. A.: Selection of bioindicators in coal-contaminated soils of Dhanbad, India, Envir. Earth Sci., 64, 1107-1115, doi:10.1007/s12665-011-0927-x, 2011b.

Mastral, A. M. and Callén, M. S.: A review on polycyclic aromatic hydrocarbon $(\mathrm{PAH})$ emissions from energy generation, Environ. Sci. Technol., 34, 3051-3057, doi:10.1021/es001028d, 2000.

Microwave assisted acid digestion of sediments, sludges, soils, and oils (USEPA 3051A), available at: http://www.epa.gov/osw/ hazard/testmethods/sw846/pdfs/3051a.pdf (last access: 30 December 2014), 2007.

Microwave Extraction (USEPA 3546), available at: http://www.epa. gov/osw/hazard/testmethods/sw846/pdfs/3546.pdf (last access: 30 December 2014), 1995.

Milder, A. I., Fernández-Santos, B., and Martínez-Ruiz, C.: Colonization patterns of woody species on lands mined for coal in Spain: preliminary insights for forest expansion, Land Degrad. Dev., 24, 39-46, doi:10.1002/ldr.1101, 2013.

Mondal, G. C., Singh, A. K., Singh, T. B., Tewary, B. K., and Sinha, A.: Wet and dry deposition of atmospheric pollutants around coal mining area of Dhanbad and Bokaro districts, Proceedings of the XI International Seminar on Mineral Processing Technology, 1137-1146, 2010.

Morugán-Coronado, A., Arcenegui, V., García-Orenes, F., MataixSolera, J., and Mataix-Beneyto, J.: Application of soil quality indices to assess the status of agricultural soils irrigated with treated wastewaters, Solid Earth, 4, 119-127, doi:10.5194/se-4119-2013, 2013.

Mukhopadhyay, S. and Maiti, S. K.: Soil $\mathrm{CO}_{2}$ flux in grassland, afforested land and reclaimed coalmine overburden dumps: a case 
study, Land Degrad. Dev., 25, 216-227, doi:10.1002/ldr.1161, 2014.

Mukhopadhyay, S., Maiti, S. K., and Masto, R. E.: Development of mine soil quality index (MSQI) for evaluation of reclamation success: A chronosequence study, Ecol. Eng., 71, 10-20, doi:10.1016/j.ecoleng.2014.07.001, 2014.

Mukhopadhyay, S., Maiti, S. K., and Masto, R. E.: Use of Reclaimed Mine Soil Index (RMSI) for screening of tree species for reclamation of coal mine degraded land, Ecol. Eng., 57, 133142, doi:10.1016/j.ecoleng.2013.04.017, 2013.

Okedeyi, O. O.: Assessment of Polycyclic Aromatic Hydrocarbons (PAHs) and heavy metals in the vicinity of coal power plants in South Africa, PhD Thesis, University of South Africa, 2012.

Ozgoz, E., Gunal, H., Acir, N., Gokmen, F., Birol, M., and Budak, M.: Soil quality and spatial variability assessment of land use effects in a typic haplustoll, Land Degrad. Dev., 24, 277-286, doi:10.1002/ldr.1126, 2013

Pallavicini, Y., Alday, J. G., and Martínez-Ruiz, C.: Factors Affecting Herbaceous Richness and Biomass Accumulation Patterns of Reclaimed Coal Mines, Land Degrad. Dev., 26, 211-217, doi:10.1002/ldr.2198, 2015.

Paz-Ferreiro, J. and Fu, S.: Biological indices for soil quality evaluation: perspectives and limitations, Land Degrad. Dev., doi:10.1002/ldr.2262, in press, 2014.

Peng, C., Chen, W., Liao, X., Wang, M., Ouyang, Z., Jiao, W., and Bai, Y.: Polycyclic aromatic hydrocarbons in urban soils of Beijing: Status, sources, distribution and potential risk, Environ. Pollut., 159, 802-808, 2011.

Pies, C., Yang, Y., and Hofmann, T.: Distribution of polycyclic aromatic hydrocarbons (PAHs) in floodplain soils of the Mosel and Saar River, J. Soils Sediments, 7, 216-222, doi:10.1065/jss2007.06.233, 2007.

Pietrzykowski, M.: Soil quality index as a tool for Scots pine (Pinus sylvestris) monoculture conversion planning on afforested, reclaimed mine land, Journal of Forestry Research, 25, 63-74, doi:10.1007/s11676-013-0418-x, 2014.

Robertson, G. P., Coleman, D. C., Bledsoe, C. S., and Phillip, S.: Standard Soil Methods for Long Term Ecological Research, Oxford University Press, Oxford, 1999.

Schwarzbauer, J.: Organic Contaminants in Riverine and Groundwater Systems - Aspects of the Anthropogenic Contribution, Springer, 464 pp., 2006.

Sharma, K. L., Mandal, U. K., Srinivas, K., Vittal, K. P. R., Mandal, B., Grace, J. K., and Ramesh, V.: Long-term soil management effects on crop yields and soil quality in a dryland Alfisol, Soil Till. Res., 83, 246-259, doi:10.1016/j.still.2004.08.002, 2005.

Sinha, S., Masto, R. E., Ram, L. C., Selvi, V. A., Srivastava, N. K., Tripathi, R. C., and George, J.: Rhizosphere soil microbial index of tree species in a coal mining ecosystem, Soil Biol. Biochem., 41, 1824-1832, doi:10.1016/j.soilbio.2008.11.022, 2009.

Soclo, H. H., Garrigues, P., and Ewald, M.: Origin of Polycyclic Aromatic Hydrocarbons (PAHs) in Coastal Marine Sediments: Case Studies in Cotonou (Benin) and Aquitaine (France) Areas, Mar. Pollut. Bull., 40, 387-396, 2000.

Srivastava, A. and Jain, V. K.: Size distribution and source identification of total suspended particulate matter and associated heavy metals in the urban atmosphere of Delhi, Chemosphere, 68, 579589, 2007
Stout, S. A and Emsbo-Mattingly, S.: Concentration and character of PAHs and other hydrocarbons in coals of varying rank - Implications for environmental studies of soils and sediments containing particulate coal, Org. Geochem., 39, 801-819, 2008.

Swaine, D. J. and Goodarzi, F.: Environmental Aspects of Trace Elements in Coal, Springer, The Netherlands, 1995.

Tandon, H. L. S.: Methods of Analysis of Soils, Plants, Waters and Fertilizers, FDCO, New Delhi, 1993.

Tizado, E. J. and Núñez-Pérez, E.: Terrestrial arthropods in the initial restoration stages of anthracite coal mine spoil heaps in northwestern Spain: potential usefulness of higher taxa as restoration indicators, Land Degrad. Dev., doi:10.1002/ldr.2280, in press, 2014

Tsibart, A., Gennadiev, A., Koshovskii, T., and Watts, A.: Polycyclic aromatic hydrocarbons in post-fire soils of drained peatlands in western Meshchera (Moscow region, Russia), Solid Earth, 5, 1305-1317, doi:10.5194/se-5-1305-2014, 2014.

USEPA: Noncarcinogenic effects of chromium: Update to health assessment document. Research Triangle Park, NC: Environmental Criteria and Assessment Office, Office of Health and Environmental Assessment, U.S. Environmental Protection Agency, EPA600887048F, 1990.

van Leeuwen, J. P., Lehtinen, T., Lair, G. J., Bloem, J., Hemerik, L., Ragnarsdóttir, K. V., Gísladóttir, G., Newton, J. S., and de Ruiter, P. C.: An ecosystem approach to assess soil quality in organically and conventionally managed farms in Iceland and Austria, SOIL, 1, 83-101, doi:10.5194/soil-1-83-2015, 2015.

Wardle, D. A. and Ghani, A.: A critique of the microbial metabolic quotient $\left(\mathrm{qCO}_{2}\right)$ as a bioindicator of disturbance and ecosystem development, Soil Biol. Biochem., 27, 1601-1610, doi:10.1016/0038-0717(95)00093-T, 1995.

Willsch, H. and Radke, M.: Distribution of polycyclic aromatic compounds in coals of high rank, Polycycl. Aromat. Comp., 7, 231-251, 1995.

Yapici, G., Can, G., Kiziler, A. R., Aydemir, B., Timur, I. H., and Kaypmaz, A.: Lead and cadmium exposure in children living around a coal-mining area in Yatagan, Turkey, Toxicol. Ind. Health, 22, 357-362, 2006.

Zhang, K., Zheng, H., Chen, F. L., Ouyang, Z. Y., Wang, Y., Wu, Y. F., Lan, J., Fu, M., and Xiang, X. W.: Changes in soil quality after converting Pinus to Eucalyptus plantations in southern China, Solid Earth, 6, 115-123, doi:10.5194/se-6-115-2015, 2015.

Zhao, X., Wu, P., Gao, X., and Persaud, N.: Soil Quality Indicators in Relation to Land Use and Topography in a Small Catchment on the Loess Plateau of China, Land Degrad. Dev., 26, 54-61, doi:10.1002/ldr.2199, 2015.

Zornoza, R., Acosta, J. A., Bastida, F., Domínguez, S. G., Toledo, D. M., and Faz, A.: Identification of sensitive indicators to assess the interrelationship between soil quality, management practices and human health, SOIL, 1, 173-185, doi:10.5194/soil-1-173-2015, 2015. 